\title{
Effects of Follow-up by Phone Interview and Anger Management Training Provided to Patients with Breast Cancer Undergoing Radiotherapy on Levels of Self-Esteem, Anger and Depression
}

\author{
Birgul OZKAN ${ }^{1}$, Selahattin MENTES ${ }^{2}$, Ahmet OZTURK $^{3}$, Serdar SOYUER ${ }^{4}$ \\ ${ }^{1}$ Yıldırım Beyazıt Universty, Faculty of Health Science, Ankara \\ ${ }^{2}$ Pirivate Island Oncology Hospital, Department of Radiation Oncology, Ordu \\ ${ }^{3}$ Erciyes University, Faculty of Medicine, Department of Biostatistics, Kayseri \\ ${ }^{4}$ Erciyes University, Faculty of Medicine, Department of Radiation Oncology, Kayseri, TURKEY
}

\begin{abstract}
Although surgery, medical oncology and radiation oncology are of importance in the management of breast cancers, psychiatry and supporting care such as psych-oncology nursing have an important role in the breast cancer. The present study aimed to measure the effect of follow-up by phone interviews and anger management training provided to patients with breast cancer on the levels of, anger, self-esteem and depression. The present study was conducted as a randomized-controlled experimental study between February, 2012 and February, 2013. The study conducted on patients with breast cancer undergoing radiotherapy in Radiation Oncology Center of Erciyes University, Mustafa Kemal Dedeman Oncology Hospital in ambulatory settings in Kayseri, Turkey. The experiment and control groups included 22 and 20 subjects, respectively. All subjects completed a survey about general characteristics, Speilberger State-Trait Anger Expression Scale, Rosenberg Self-Esteem Scale and Beck Depression Inventory. A significant difference was found between study and control groups in terms of mean overall anger, self-esteem and Beck Depression scores $(p<0.001)$. A significant difference was found between measurements $(p<0.001)$. It is recommended to provide home-based care (e.g. phone interviews, home visits) following anger management training in patients with breast cancers and to arrange education program in those receiving radiotherapy.
\end{abstract}

Keywords: Breast cancer, Anger training, Follow-up by phone, Self-Esteem, Depression

ÖZET

Radyoterapi Alan Meme Kanserli Hastalara Verilen Öfke Eğitiminin ve Telefon İzleminin Hastaların Benlik Saygısı, Öfke, Depresyon Düzeylerine Etkisi

Meme kanserinin tedavisinde cerrahi, medikal ve radyasyon onkolojisi birincil önemde olmasına rağmen radyoloji, patoloji, plastik cerrahi, psikiyatri ve psikonkoloji hemşireliği gibi destek hizmetleri de önemli rol oynamaktadır. Bu çalışma radyoterapi alan meme kanserli hastalara yapılan öfke eğitiminin ve telefonla yapılan izleminin hastaların benlik saygılarına, öfke ve depresyon düzeylerine etkisini ölçmek amacıyla yapılmıştır. Bu araştırma rastgele kontrollü deneysel çalışma olarak şubat 2012 ile şubat 2013 tarihleri arasında yapılmıştır. Araştırma, Erciyes Üniversitesi Mustafa Kemal Dedeman Onkoloji Hastanesi'ne bağı Radyasyon Onkoloji merkezinde izlenen ve klinikte ayaktan radyoterapi alan meme kanserli hastalar ile yapılmıştır. Deney grubuna 22 ve kontrol grubuna ise 20 hasta alınmıştır. Araştırmada her iki gruptaki hastalara da, tanııı özellikleri içeren anket formu, Rosenberg Benlik Saygıı Ölçeği, Speilberger Öfke Süreklilik ve Öfke Ifade Tarzları Ölçeği, Beck Depresyon Ölçeği uygulanmıştır. Öfke, Benlik saygısı, Beck depresyon genel puan ortalamalarına göre deney ve kontrol grupları arasında istatistiksel olarak önemli bir fark bulunmuştur ( $p<0.001)$. Ölçümler arasında istatistiksel olarak anlamlı bir fark bulunmuştur ( $p<$ 0.001). Radyoterapi alan meme kanserli hastalara öfke yönetimine ilişkin verilen eğitimin devamında evde izlemlerinin (telefon, ev ziyareti vb) sağlanması, klinikte radyoterapi alan hastaların eğitim programlarının düzenlemesi önerilmektedir.

Anahtar Kelimeler: Meme kanseri, Öfke eğitimi, Telefon izlemi, Benlik saygısı, Depresyon 


\section{INTRODUCTION}

Breast cancer is the most common one of the nondermatological cancers and second leading cause of cancer-related deaths following lung cancers among women. Over last decade, mortality rate of the breast cancer has decreased by $2 \%$. Radiotherapy has a major role at every level of breast cancers. The radiotherapy plays a significant role in the management of breast cancers including ductal carcinoma in situ as a component of breast-sparing surgery and locally advanced disease as an adjuvant therapy after mastectomy; and even in metastatic disease with palliative purposes. ${ }^{1-3}$

In the management of the breast cancer, a multidisciplinary approach should be used by taking tumor size, pathological diagnosis, age, menopausal status, hormonal status and psychological status into consideration. Although surgery, medical therapy and radiotherapy have primary role in the management of breast cancer, radiology, pathology, plastic surgery, psychiatry and supportive care such as psycho-oncology nursing play important role. ${ }^{1,2}$. Thus, it has been observed that many patients are facing with several psychological problems and these patients don't know how to cope with these problems. $^{6-9}$

Factors contributing to development of psychological disorder after diagnosis and treatment (even after several years) include fear of death and recurrence, impaired body image and changes in feminity, sexuality and attractiveness. ${ }^{3,6,7}$ The cancer-related psychiatric dissorders and cancer psychiatry have been investigated in many studies. ${ }^{7,9}$

Depression is a syndrome characterized by sadness as well as both sadness and anxious mood in some occasions with slowing and stagnating thoughts, speech, motion and physiological functions as well as feelings and thoughts of worthless, meanness, weakness, unwillingness and pessimism. The depression is commonly observed in patients with breast cancer as similar to those with any type of cancer. ${ }^{3-5,8,9}$

As depression is associated to anger directed to ego, building up effective skills for coping with anger is rather important in the prevention of depression. The studies show that structured psychological training directed to the patients with breast cancer and follow-up are effective in reducing levels of depression and anger. ${ }^{9-11}$ Several evidence have found that psychosocial interventions in patients with cancer improve quality of life in these patients; facilitate the management of physical adverse effects; and improve psychological status., ${ }^{4,8,9,12}$

There are many psychosocial interventions for patients with breast cancer undergoing radiotherapy and chemotherapy. It has been suggested that telepsychiatric follow-up is an effective innovation which can be used in clinical care, education and investigation. ${ }^{13-15}$

The telepsychiatric follow-up can be provided by several ways including video conference, e-mail or web pages. When pooled results of the studies on this issue were reviewed, it was found that education, counseling and follow-up by phone interviews improved the psychosocial adaptation levels in the patients. ${ }^{10,11,13}$ Previous studies have shown that phone interviews in patients with breast cancer are inexpensive and improve their adaptation to society. ${ }^{11-15}$ By considering these studies, follow-up by phone interviews can be used to ensure continuity of psycho-oncology care in an effective manner and to maintain nursing care.

To best of our knowledge, there is no study involving follow-up by phone interview in patients with breast cancer in Turkey. In current healthcare system in Turkey, the management and care are largely provided during hospital admission, while no homebased care is provided after discharge. The support and counseling by phone interviews after training of anger management can make the patients to feel that they are not alone and that the management and care are maintained at home. This can reduce the problems faced by patients regarding management of the disease and improve skills of coping with these problems.

The present study aimed to measure the effects of follow-up by phone interview and anger management training provided to patients with breast cancer on the levels of self-esteem, anger and depression.

\section{PATIENTS AND METHODS}

The present study was conducted as a randomizedcontrolled experimental study (including experimental and control groups with pretest and posttest design) between February, 2012 and February, 2013. It was approved by Kayseri Province Ethics 
Committee I (01.11.13; \#2012/145) in Kayseri, Turkey.

The study conducted on patients with breast cancer who received radiotherapy in Radiation Oncology Center of Erciyes University, Mustafa Kemal Dedeman Oncology Hospital in ambulatory settings in Kayseri, Turkey. The experimental and control groups included 22 and 20 subjects, respectively. The sample size was large enough to allow adequate statistical power to clearly determine the intervention's effectiveness. The use of randomization allowed to obtain two groups of patients with very similar baseline

The hospitalized patients which fulfileld the inclusion criteria were given the odd numbers for the experimental and dual numbers for the control group. After the data collection, PASS 11 (Power Analysis $\&$ Sample Size Software) was used to determine the number of samples in each group, $\alpha=0.05$, power as $\% 100$ in the power analysis of all scales used in the study. The research was conducted randomly with a sample set of criteria which was age, educational status and pathological state of the patients. After identifying the experimental and control group all the scales were applied to both groups. All scales used in this study were filled out by the researcher through face to face interviews with patients with breast cancer in the experimental group during the hospitalization (before training), on discharge (after training), and after the 6-month follow-up by phone.
In the present study, both experimental and control groups completed a survey about general characteristics, Speilberger State-Trait Anger Expression Scale, Rosenberg Self-Esteem Scale and Beck Depression Inventory.

Patient selection criteria for experimental and control groups;

- Being aged between 18 and 65 years

- Having breast cancer at stages of 1, 2 or 3

- Being graduated from primary school

\section{General Survey Sheet}

The survey sheet included 15 questions about demographic features of the subjects as well as another 15 questions about disease history

Speilberger State-Trait Anger Expression Scale

These scales were developed by Speilberger et al. in $1983^{16}$ and Turkish validity and reliability were demonstrated in 1994 by Özer. ${ }^{17}$ The Speilberger Anger State scale attempts to understand how the individual feel himself in general, while the Anger Expression scale attempts to evaluate by which frequency the individual behaves in the stated-manner. Items are randomly distributed in Anger Expression scale. The answers include "almost never" (1), "sometimes" (2), "often" (3) and "almost always" (4). Each subscale includes 8 items.

\begin{tabular}{|l|l|}
\hline Table 1. The content of anger and management skills training anger & Session \\
\hline Topic & Duration(min) \\
\hline What is anger? & 30 min \\
In general, how does the feeling of anger develop? & \\
The importance of the relationship between anger development and defense mechanisms of ego? \\
Why the content of thought underlying the feel of anger is important? \\
The development of anger-related behaviors and the importance of the knowledge about this mechanism \\
What is the beneficial feature of anger? \\
Summary and repeat of the topic \\
How does harming feature of anger develop? \\
The ways to effectively cope with anger and its relationship with psychosomatic diseases \\
Discussion of the mechanism which are used to cope with anger by patients and sharing feelings after interactive discussion \\
Improving skills for effective coping with anger \\
Improving expression of anger via "Expressing feeling with I language" (Role Play) \\
Repeat and Completion of Training
\end{tabular}


International Journal of Hematology and Oncology

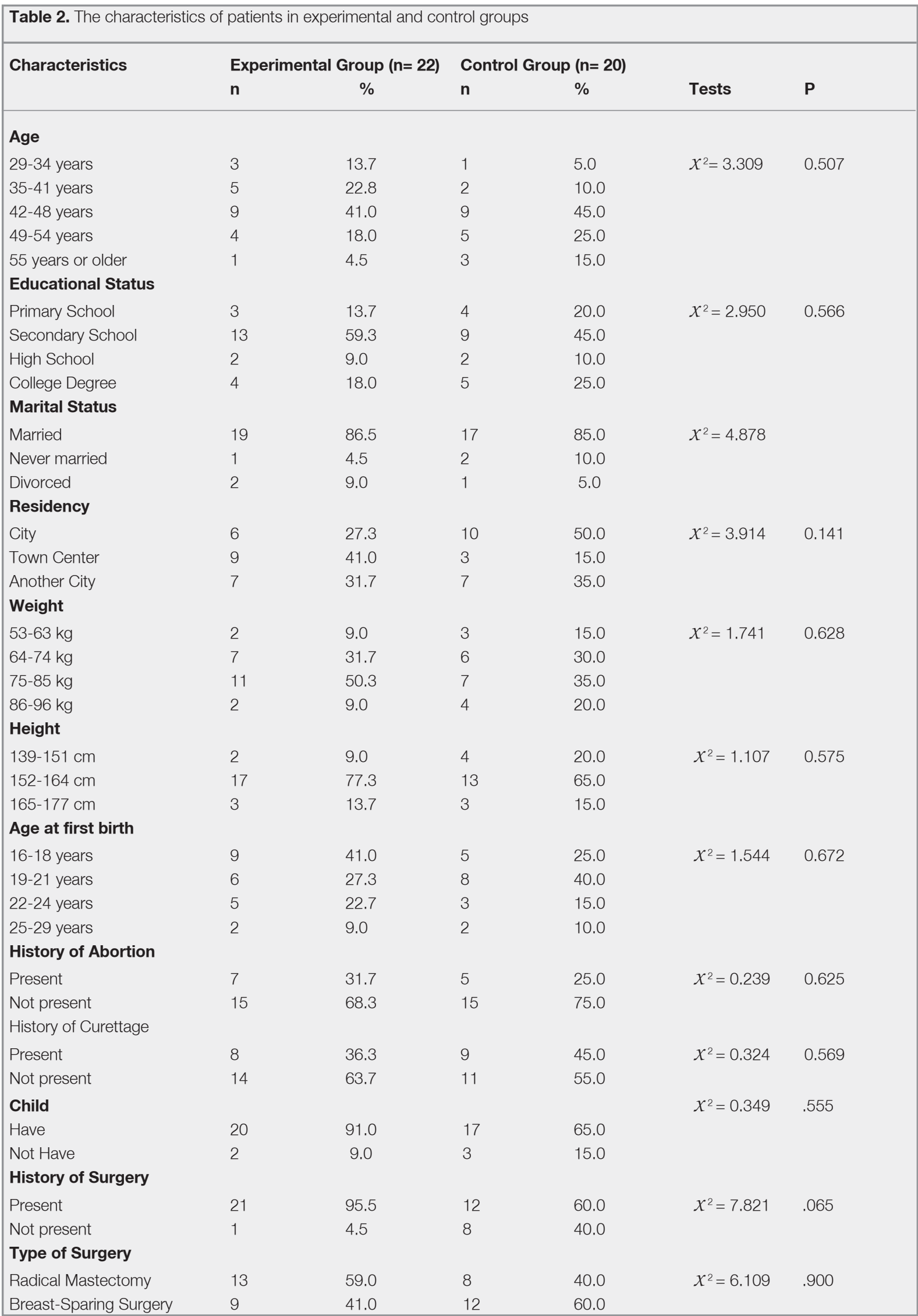

UHOD Number: 4 Volume: 24 Year: 2014 
International Journal of Hematology and Oncology

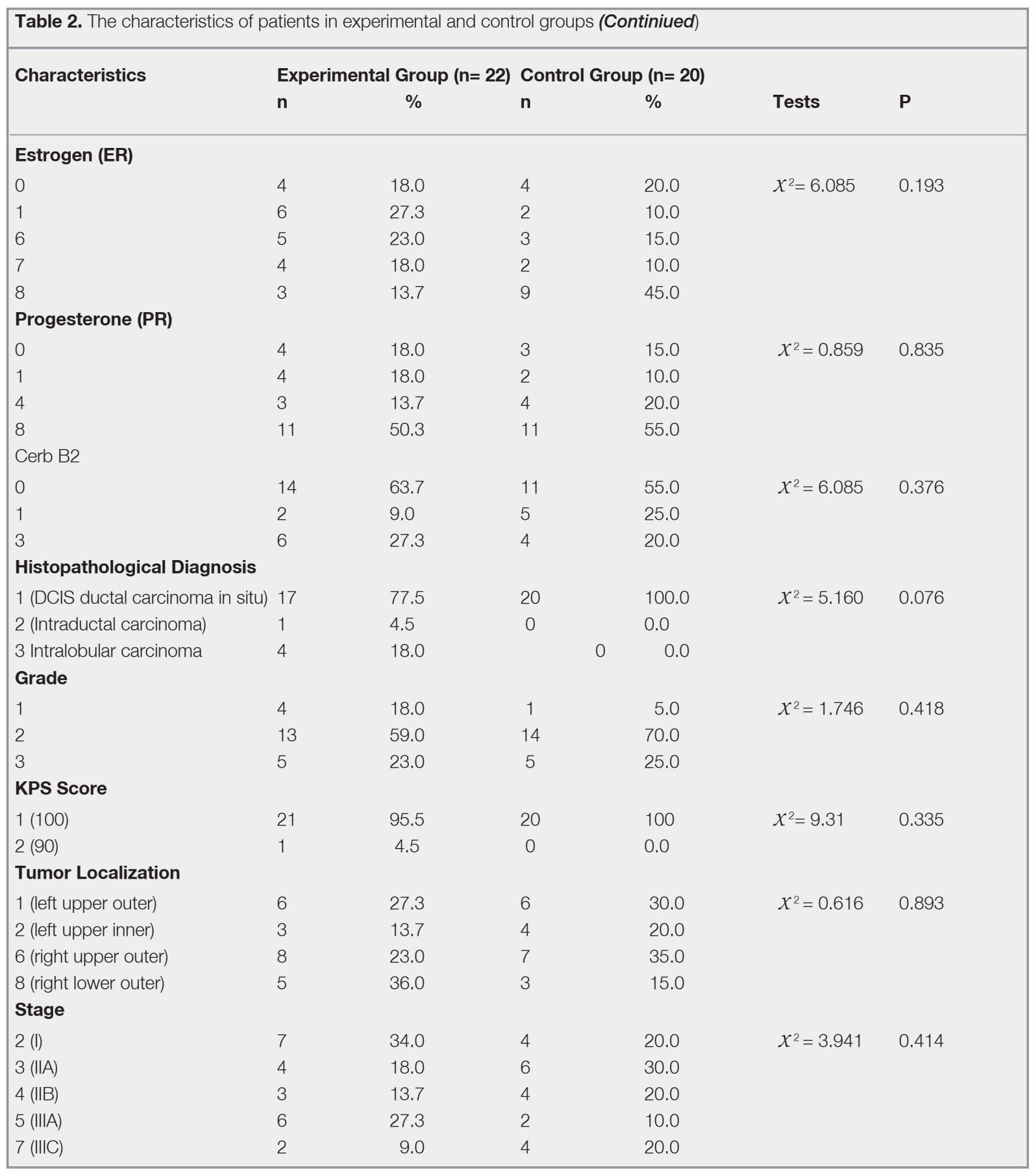

\section{Rosenberg Self-Esteem Scale}

This scale was developed by Rosenberg in $1965 .{ }^{18}$ The Turkish validity and reliability were demonstrated in 1986 by Cuhadaroglu ${ }^{19}$ and reliability coefficient was found as 0.75 . In that study, alpha value for Rosenberg Self-Esteem scale was found as 0.65 . The scale includes 63 questions in 12 do- mains. First 10 items of the scale was used for the purposes of the present study. In the first 10 items, total score of 0-1 indicates high self-esteem, while scores of 2-4 and 5-6 indicate moderate and low self-esteem, respectively. 


\begin{tabular}{|c|c|c|c|c|c|c|}
\hline \multirow[t]{2}{*}{ Groups } & Time & $\begin{array}{l}\text { Anger } \\
\text { Control }\end{array}$ & $\begin{array}{l}\text { Persistent } \\
\text { Anger }\end{array}$ & Anger-In & Anger-Out & $\begin{array}{l}\text { Overall Anger } \\
\text { Score }\end{array}$ \\
\hline & & $\bar{X} \pm \mathrm{SS}$ & $\bar{x} \pm \mathrm{SS}$ & $\bar{x} \pm \mathrm{SS}$ & $\bar{X}_{ \pm} \mathrm{SS}$ & $\bar{x} \pm \mathrm{SS}$ \\
\hline \multirow[t]{3}{*}{ Experimental } & Before Training & $7.81 \pm 4.63^{a}$ & $18.50 \pm 6.75^{a}$ & $14.54 \pm 5.19^{a}$ & $13.40 \pm 4.81^{a}$ & $54.27 \pm 17.22^{\mathrm{a}}$ \\
\hline & After Training & $13.30 \pm 3.77^{b}$ & $14.18 \pm 3.17^{b}$ & $12.18 \pm 3.69^{a}$ & $12.27 \pm 3.70^{\mathrm{a}}$ & $50.27 \pm 9.95^{a}$ \\
\hline & After Follow-up & $14.15 \pm 3.09^{c}$ & $8.00 \pm 3.97^{c}$ & $8.13 \pm 2.67^{b}$ & $8.36 \pm 3.18^{b}$ & $32.77 \pm 9.76^{b}$ \\
\hline \multirow[t]{3}{*}{ Control } & Before Training & $12.70 \pm 3.71^{a}$ & $17.40 \pm 5.13^{\mathrm{a}}$ & $13.90 \pm 4.16^{a}$ & $11.10 \pm 3.41^{a}$ & $55.10 \pm 8.86^{a}$ \\
\hline & After Training & $11.63 \pm 3.20^{\mathrm{a}}$ & $18.00 \pm 4.12^{\mathrm{a}}$ & $18.40 \pm 2.58^{b}$ & $9.60 \pm 3.40^{a}$ & $59.30 \pm 5.52^{a}$ \\
\hline & After Follow-up & $8.27 \pm 2.31^{a}$ & $12.30 \pm 4.25^{b}$ & $12.10 \pm 3.21^{\mathrm{a}}$ & $12.25 \pm 3.60^{a}$ & $50.80 \pm 5.92^{b}$ \\
\hline \multirow[t]{7}{*}{ Test } & & $F$ & $F$ & $F$ & $F$ & $F$ \\
\hline & Time & 4.510 & 32.949 & 22.840 & 3.330 & 21.202 \\
\hline & Time+ Group & 4.454 & 4.454 & 9.371 & 11.453 & 7.018 \\
\hline & Group & 37.104 & 7.042 & 26.627 & 0.245 & 25.777 \\
\hline & $\mathbf{P}^{*}$ & $<0.001$ & $<0.05$ & $<0.001$ & $>0.05$ & $<0.001$ \\
\hline & $\mathbf{P +}$ & $<0.05$ & $<0.05$ & $<0.001$ & $<0.001$ & $<0.05$ \\
\hline & P\# & $<0.001$ & $>0.05$ & $<0.001$ & $<0.05$ & $<0.001$ \\
\hline
\end{tabular}

\section{Beck Depression Inventory}

The scale was developed by Beck et al. in $1961^{20}$ in order to observe the symptoms and depressionspecific attitudes in clinical manner and to gather frequently observed behaviors together. The scale was adapted to Turkish by Hisli in $1988 .{ }^{21}$ The clinical observations were systematically collected in 21 symptoms and attitudes were graded as $0-3$ according to intensity. Although cut-off point varies in different studies, it has been suggested that 17 points would be adequate to identify clinical depression. ${ }^{6,20,21}$ Overall score varies between 0 and 63 points.

\section{Phases of Investigation}

The patients in experimental group received anger management training during the radiotherapy period. Anger management trainings were given by 2 or 3 sessions according to Anger Management Training for Patients with Breast Cancer Manual (Table 1). Each session was performed over 25-30 minutes. During this period, controls underwent no intervention.

After radiotherapy, follow-up by phone interview (weekly, at a certain day and hour) were performed for 6 months in experimental group. Phone interviews included repeat of anger management training, counseling and the issues faced by patients. In the present study, telepsychiatric follow-up was performed according to Phone Interview Form for Patients with Breast Cancer which was developed by researchers.

In all subjects, Speilberger State-Trait Anger Expression Scale, Rosenberg Self-Esteem Scale, and Beck Depression Inventory were completed by researchers via face-to-face interview during radiotherapy, one month after anger management training and 6-months follow-up period achieved by phone interviews.

The data obtained from subjects in experimental and control groups were analyzed by using (chisquare) significance test, "Student t test and twoway analysis of variance for repeated measurements. Bonferroni and LSD tests were performed to identify the source of difference in the variables that are found to be significance in the analysis of variance. All statistical analyses were performed by using SPSS Statistics 20.0 (IBM SPSS Inc, Chicago, ILL, USA). $\mathrm{P}<.05$ was considered as significant. 
Table 4. The mean scores of self-esteem of the patients in the experimental and the control groups before, after the traning and after follow-up

\begin{tabular}{|c|c|c|}
\hline Groups & Time & $\begin{array}{l}\text { Overall Self- } \\
\text { Esteem Scores } \\
\bar{X} \pm S S\end{array}$ \\
\hline \multirow[t]{3}{*}{ Experimental } & Before Training & $3.51 \pm 1.05^{\mathrm{a}}$ \\
\hline & After Training & $1.72 \pm 0.69^{b}$ \\
\hline & After Follow-up & $1.06 \pm 0.46^{c}$ \\
\hline \multirow[t]{3}{*}{ Control } & Before Training & $3.02 \pm 0.59^{a}$ \\
\hline & After Training & $3.20 \pm 0.55^{\mathrm{a}}$ \\
\hline & After Follow-up & $3.38 \pm 0.58^{b}$ \\
\hline \multirow[t]{7}{*}{ Test } & & $F$ \\
\hline & Time & 42.559 \\
\hline & Time+ Group & 77.240 \\
\hline & Group & 45.261 \\
\hline & $\mathbf{P}^{*}$ & $<0.001$ \\
\hline & $\mathbf{P}+$ & $<0.001$ \\
\hline & P \# & $<0.001$ \\
\hline \multicolumn{3}{|c|}{$\begin{array}{l}P^{*}=\text { between groups; } P+=\text { between measurements } / \text { times; } \\
P \#=\text { group-time interaction }\end{array}$} \\
\hline \multicolumn{3}{|c|}{$\begin{array}{l}\text { The results of multiple comparisons within experimental and } \\
\text { control groups are expressed as alphabetic superscripts; identi- } \\
\text { cal superscripts indicate insignificant difference, while non-iden- } \\
\text { tical superscripts indicate significant difference between groups. }\end{array}$} \\
\hline
\end{tabular}

\section{RESULTS}

The age, educational status and pathological state of the patients were selected to be similar and no significant difference was found between experiment and control groups ( $\mathrm{p}>0.05$; Table 2 ).

Table 3 presents mean scores in anger scales and subscales of the patients in experiment and control groups after anger management training and follow-up period. The group effect on mean overall anger score was found to be significant $(\mathrm{p}<0.001)$. Measurement/time effect on mean anger score was also found to be significant ( $\mathrm{p}<0.05$; Table 3 ). In the multiple comparisons performed to identify the source of difference in the experiment group, mean overall anger score after follow-up was found to be significantly lower compared to those obtained both before and after training. In the multiple compari-

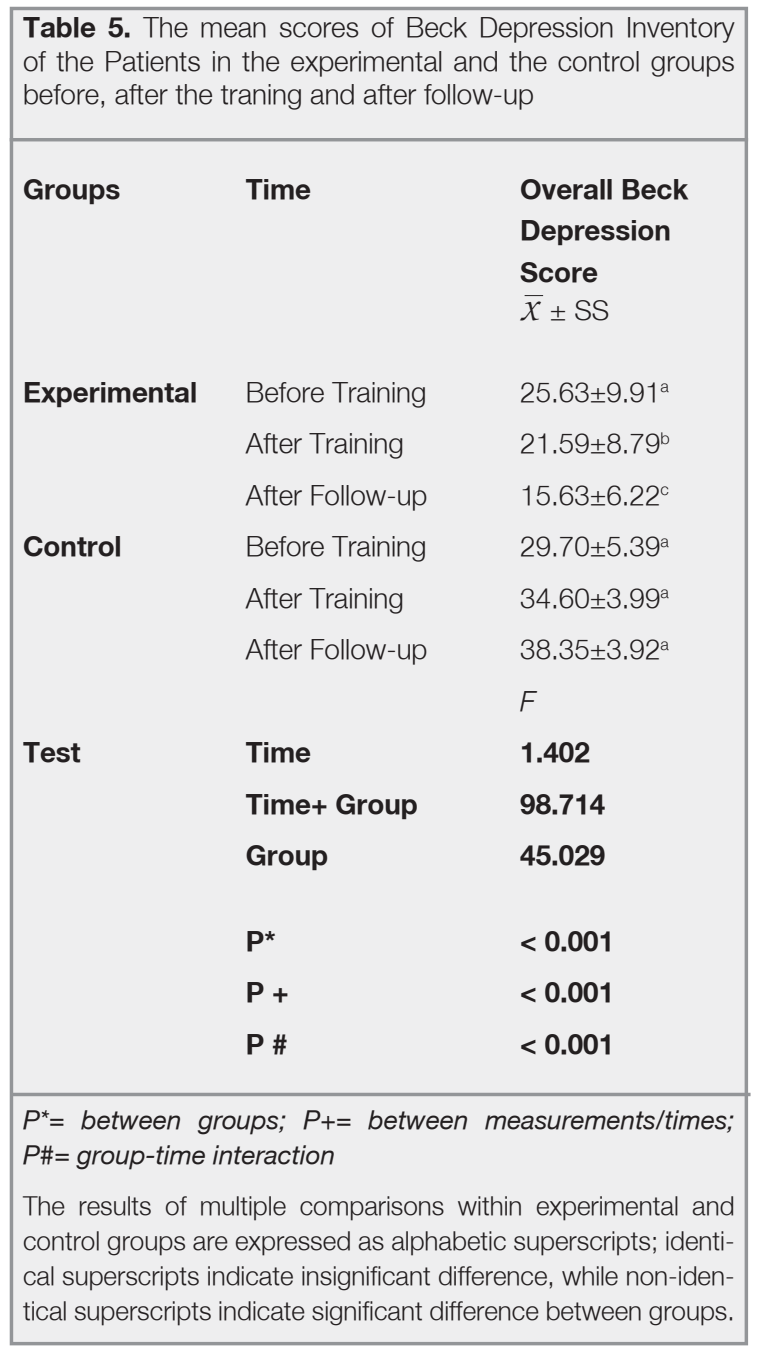

sons performed to identify the source of difference in the control group, the difference was found to be significant in the comparison of mean anger score obtained after training to those obtained after follow-up, while no significant difference was found in other comparisons. The group and time interactions of mean anger scores were found to be significant $(\mathrm{p}<0.001$; Table 3$)$. Table 3 presents mean scores of anger control, persistent anger, anger-in, anger-out subscales in the experiment and control groups.

Table 4 presents mean overall self-esteem scores of subjects in experiment and control groups obtained before and after training as well as those obtained after follow-up period. The group effect on mean overall self-esteem score was found to be significant $(\mathrm{p}<0.001$; Table 4). In the multiple comparisons performed to identify the source of difference in the 
experiment group, mean overall self-esteem score obtained after follow-up period was found to be significantly lower compared to those obtained both before and after training $(\mathrm{p}<0.001)$. In the multiple comparisons performed to identify the source of difference in the control group, no significant difference was found in mean overall self-esteem scores obtained after follow-up compared to those obtained both before and after training ( $p>0.05$; Table 4$)$.

The group effect on mean overall Beck depression score was found to be significant $(\mathrm{p}<0.001)$. The measurement/time effect on mean overall Beck depression score was found to be significant $(\mathrm{p}<0.001$; Table 5). In the multiple comparisons performed to identify the source of difference in the experiment group, mean overall Beck depression score obtained after follow-up period was found to be significantly lower compared to those obtained both before and after training $(\mathrm{p}<0.001)$. In the multiple comparisons performed to identify the source of difference in the control group, the difference was found to be significant in the comparison of mean depression score obtained after training to those obtained after follow-up, while no significant difference was found in other comparisons $(\mathrm{p}<0.05)$.

\section{DISCUSSION}

Phone and videotapes are known to be technologies commonly used in the education of patients. Phone interviews are an effective method to provide information and support to individuals and groups in cancers as well as several chronic diseases. ${ }^{9-14,22}$ In several studies, they was found that, by this method, the level of knowledge is increased in patient receiving chemotherapy while symptoms related to chemotherapy are decreased..$^{12,23-25}$

In our study, no significant difference was found between experiment and control groups regarding mean overall anger scores obtained before training ( $p>0.05$ ). In addition, no significant difference was found between mean overall anger scores obtained before and after training in experiment group ( $\mathrm{p}>$ $0.05)$. In experiment group, it was found that there was a significant difference between mean overall anger scores obtained before and after training compared to those obtained after follow-up period ( $\mathrm{p}<$ 0.001). In the control group, it was found that there was no significant difference in mean overall anger scores obtained before and after training compared to those obtained after follow-up ( $>>0.05$ ); howev$\mathrm{er}$, a significant difference was found between mean overall anger scores obtained after training and those obtained after follow-up ( $<<0.05$; Table 3 ). According to our results, it was seen that anger score was gradually decreased in patients in whom information and support was provided by phone interviews, while it continued to increase in the control group. In this context, our results were in agreement with those obtained by other groups. The previous studies demonstrated that patients receiving information and support can more conveniently cope with conditions causing psychological distress such as anger, hopelessness or ambiguousness. . $^{80,13,14,22,26,27}$

In the literature, it has been shown that there are some changes in the feeling of identity and ego; thus, there may be a decrease in self-esteem in patients with breast cancer. ${ }^{4-7,12,28}$ In patients with breast cancer, it is thought that this could be due experiencing alterations in body image and selfesteem with changes in their body. Before training, no significant difference was found between experiment and control groups regarding mean self-esteem score $(\mathrm{p}>0.05)$. In experiment group, it was found that there was a significant difference between mean self-esteem scores obtained before and after training as well as between those obtained before training and after follow-up period ( $p>0.001)$. In control group, it was found that there was no significant difference between mean self-esteem scores obtained before and after training ( $p>0.05)$, while there was a significant difference in those obtained before and after training compared to those obtained after follow-up period ( $p<0.05$; Table 4$)$. Several studies are in agreement with our results. ${ }^{9-14,29}$ Data obtained in our study can be interpreted as the phone interviews and anger management trainings have positive effects on self-esteem of the patients in experiment group. However, it was found that self-esteem could be reduce in control subjects who experienced routine practice and didn't receive any intervention.

It is well-known that anxiety and depression are the most common psychosocial problems experienced by patients with breast cancer. It is of importance to protect these patients from many psychological disorders, mainly from depression. As the depression is associated with anger directed to ego, the improvement of effective coping skills with anger is of importance in the prevention of depression. Previous 
studies demonstrated that structured psychological training directed to patients with breast cancer and follow-up are effective in reducing depression levels in these patients. . $^{3-8,10,28,30}$ In our study, no significant difference was found between experiment and control groups regarding mean Beck depression scores before training ( $>0.05)$. Moreover, no significant difference was found between mean Beck depression scores obtained before and after training in experiment group ( $p>0.05)$. In experiment group, it was found there was a significant difference in mean Beck depression scores obtained before and after training compared to those obtained after follow-up period ( $\mathrm{p}<0.001)$. In control group, it was found there was no significant difference in mean Beck depression scores obtained before training compared to those obtained after training and after follow-up period ( $p>0.05$ ); however, a significant difference was observed in mean Beck depression scores obtained after training and follow-up period ( $p<0.05$; Table 5). According to our results, it is thought the depression is rather prevalent in patients receiving radiotherapy, while anger management training and follow-up by phone interviews are essential to reduce level of depression. It may be suggested that the level of depression continuously increased in controls during radiotherapy; thus, the patients managed with routine clinical practice at hospitals are associated with severe risk for depression. ${ }^{9-14,22-26,31}$

Limitations: This study has some limitations. While anger management training was planned as 2 sessions lasting 25 minutes in patients with breast cancer, some variations occurred in the number and duration of sessions due to individual characteristics of the patients and discussion on the questions asked by patients about their psychological status. The sample size was large enough to allow adequate statistical power to clearly determine the intervention's effectiveness.

\section{CONCLUSIONS}

It is recommended to provide home-based care (e.g. phone interviews, home visits) following anger management training in patients with breast cancers and to arrange education program in those receiving radiotherapy. It is also recommended to conduct studies with prolonged follow-up period to assess the effectiveness of follow-up provided to the patients with breast cancers by using phone interviews. Further studies using telepsychiatric follow-up methods other than phone interview such as e-mail or web-based follow-up in order to provide home-based follow-up to the patients are needed.

\section{REFERENCES}

1. Gunderson LL, Tepper, JE. Conformal Therapy and IntensityModulated Radiation Therapy: Treatment Planning, Treatment Delivery, and Clinical Results. Clinical Radiation Oncology. 3rd edition. Philadelphia, PA: Saunders; 2012: 287-316.

2. Maslin-Prothero $S$. The role of the multidisciplinary team in recruiting to cancer trials. Eur J Cancer Care (Engl) 15: 146154, 2006.

3. Prades J, Borràs JM. Multidisciplinary cancer care in Spain, or when the function creates the organ: qualitative interview study. BMC Public Health 11: 141-151, 2011.

4. Lebel S, Rosberger Z, Edgar L, et al. Emotional distress impacts fear of the future among breast cancer survivors not the reverse. J Cancer Surviv 117: 127, 2009.

5. Grabsch B, Clarke DM, Love A, et al. Psychological morbidity and quality of life in women with advanced breast cancer: a cross-sectional survey. Palliat Support Care 4: 47-56, 2006.

6. Vahdaninia M, Omidvari S, Montazeri A. What do predict anxiety and depression in breast cancer patients?: A follow-up study. Soc Psychiatry Psychiatr Epidemiol 45: 355 61, 2010.

7. Mehnert A, Koch U, Schulz H, et al. Prevalence of mental disorders, psychosocial distress and need for psychosocial support in cancer patients - study protocol of an epidemiological multi-center study. BMC Psychiatry 12: 70-79, 2012.

8. Holland J, Andersen B, Breitbart W, et al. Distress management. J Natl Compr Canc Netw 8: 448-485, 2010.

9. Hartmann M, Bazner E, Wild B, et al. Effects of interventions involving the family in the treatment of adult patients with chronic physical diseases: a meta-analysis. Psychother Psychosom 79: 136-48, 2010.

10. Taggart F, Donnelly P, Dunn J. Options for early breast cancer follow-up in primary and secondary care: a systematic review. BMC Cancer 12: 238-250, 2012.

11. Donnelly JM, Kornblith AB, Fleishman S, et al. A pilot study of interpersonal psychotherapy by telephone with cancer patients and their partners. Psychooncology 9: 44-56, 2000.

12. Loh SY, Ong L, Ng LL, et al. Qualitative experiences of breast cancer survivors on a self-management intervention: 2 year post-intervention. Asian Pacific J Canc Prev 12: 1489-1495, 2011.

13. Beaver K, Tysver-Robinson D, Campbell M, et al. Comparing hospital and telephone follow-up after treatment for breast cancer: randomised equivalence trial. BMJ 338: 3147-3157, 2009. 
14. Sandgren AK, McCaul KD. Long-term telephone therapy outcomes for breast cancer patients. Psychooncology 16: 3847, 2007.

15. Andersen BL, Yang HC, Farrar WB, et al. Psychologic intervention improves survival for breast cancer patients: a randomized clinical trial. Cancer 113: 3450-3458, 2008.

16. Spielberger CD, Jacobs EH, Russel FS, et al. Assessment of anger: The state- trait anger scale. Advances in Personality Assessment, Butcherand JN, Spielberger CD (eds), LEA Hillsdade NJ; 2: 159-187, 1983.

17. Özer K. Preliminary study of trait anger and anger expression scales. Turkish Journal of Psychology 9: 26-35, 1994.

18. Rosenberg M. Society and The Adolescent Self-Image. Princeton University Press, 1965.

19. Cuhadaroglu F. Self-esteem in adolescents. Hacettepe Universty Department of Psychiatry Gradaute Thesis, Ankara, 1986.

20. Beck AT, Ward CH, Mendelson M, Mock J, et al. An inventory for measuring depression. Arch Gen Psychiatry 4: 561-571, 1961.

21. Hisli N. Reliability and validity of Beck Depression Inventory for university students. J Turkish Psychol 7: 3-13, 1989.

22. Lewis R, Neal RD, Williams NH, et al. Nurse-led vs. conventional physician-led follow up for patients with cancer: systematic review. J Adv Nurs 65: 706-723, 2009.

23. Cox K, Wilson E. Follow-up for people with cancer: nurse-led services and telephone interventions. J Adv Nurs 43: 51-61, 2003.

24. Koinberg IL, Fridlund B, Engholm GB. Nurse-led follow-up on demand or by a physician after breast cancer surgery: a randomised study. Eur J Oncol Nurs 8: 109 117- 120, 2004.

25. Montgomery DA. Follow-up by telephone after treatment for breast cancer. BMJ 338: 2753, 2009.
26. Butow P, Cockburn J, Girgis A, et al. Increasing oncologists' skills in eliciting and responding to emotional cues: evaluation of a communication skills training program. Psychooncology 17: 209-218, 2008.

27. Montgomery DA, Krupa K, Wilson C, et al. Automated telephone follow-up after breast cancer: an acceptability and feasibility pilot study. Br J Cancer 99: 704-710, 2008.

28. Spiegel D. Psychosocial aspects of breast cancer treatment. Semin Oncol 24: 36-47, 1997.

29. Marcus AC, Garrett KM, Cella D, et al. Can telephone counseling post-treatment improve psychosocial outcomes among early stage breast cancer survivors? Psychooncology 19: 923-932, 2009.

30. Reich M, Lesur A, Perdrizet-Chevallier C. Depression, quality of life and breast cancer: a review of the literature. Breast Cancer Res Treat 110: 9-17, 2008.

31. Kimman ML, Bloebaum MF, Carmen DD, et al. Patient satisfaction with nurse-led telephone follow-up after curative treatment for breast cancer. BMC Cancer 10: 174, 2010.

\section{Correspondence}

Dr. Birgül ÖZKAN

Yıldırım Beyazıt Üniversitesi

Sağlık Bilimleri Fakültesi

Çankıı Cad. Çiçek Sokak, No: 3

Rektörlük Binası

Ulus / ANKARA

Tel: (+90.312) 3241555

e-mail: ozkanbirgul7@gmail.com 